\title{
ХРОНККА
}

\section{МЕЖВУЗОВСКАЯ КОНФЕРЕНЦИЯ ПО ТВЕРДЫМ ДИЭЛЕКТРИКАМ И ПОЛУПРОВОДНИКАМ}

С 3 по 8 февраля 1958 г. в Томском политехническом институте состоялась межвузовская конференция по твердым диэлектрикам н полупроводникам. В работе конференции приняли участие представители 12 вузов, 10 научно-исследовательских институтов и 11 заводов из 14 городов страны.

Работа конференции проходила в 6 секциях. На пленарных и секционных заседаниях было заслушано 83 доклада. Обсуждение докладов показало, что в ряде высших учебных заведений (Ленинградском и Томском политехнических институтах, Ленинградском и Новосибирском электротехнических институтах, Днепропетровском, Иркутском и Томском университетах и др.), научно-исследова-

Поступила в редакцию

24 III 1958 r. тельских институтах и промышленных предприятиях достигнуты серьезные успехи в вопросах методики исследования свойств диэлектриков и полупроводников, определения параметров полупроводниковых прнборов; изучения природы пробоя, поляризации, потерь и проводимости в диэлектриках; создания научно-обоснованных технологических приемов изготовления $p-n$ переходов; разработки теории диэлектриков и полупроводников.

Доложенные на конференции результаты исследований наряду с их теоретической ценностью имеют важное значение для получения диэлектриков и полупроводников с заранее заданными свойствами.

Инж. В. Д. Кучин 